\title{
BAY 58-2667, a soluble guanylate cyclase activator, improves cardiopulmonary haemodynamics in acute decompensated heart failure and has a favourable safety profile
}

\author{
Harald Lapp*1, Veselin Mitrovic ${ }^{2}$, Norbert Franz ${ }^{3}$, Hubertus Heuer ${ }^{4}$, \\ Michael Buerke ${ }^{5}$, Judith Wolfertz ${ }^{6}$, Wolfgang Mück ${ }^{7}$, Sigrun Unger ${ }^{8}$, \\ Georg Wensing7 and Reiner Frey ${ }^{7}$
}

\author{
Email: Harald Lapp* - harald.lapp@helios-kliniken.de \\ * Corresponding author \\ from $3^{\text {rd }}$ International Conference on cGMP Generators, Effectors and Therapeutic Implications \\ Dresden, Germany. I5-17 June 2007 \\ Published: 25 July 2007 \\ BMC Pharmacology 2007, 7(Suppl I):S9 doi:I0.1I86/I47I-22I0-7-SI-S9
}

Address: ${ }^{1}$ HELIOS-Klinikum Erfurt, 99089 Erfurt, Germany, ${ }^{2}$ Kerckhoff-Klinik Nauheim, 61231 Nauheim, Germany, ${ }^{3}$ Schüchtermann-Klinik Bad Rothenfelde, 49214 Bad Rothenfelde, Germany, ${ }^{4}$ St Johannes Hospital Dortmund,44137 Dortmund, Germany, ${ }^{5}$ Universität Halle, 06097 Halle, Germany, ${ }^{6}$ HELIOS-Klinikum Wuppertal, 42283 Wuppertal, Germany, ${ }^{7}$ Clinical Pharmacology, Bayer HealthCare AG, Pharma Research Centre, 42096 Wuppertal, Germany and ${ }^{8}$ Global Biostatistics, Bayer HealthCare AG, Pharma Research Centre, 42096 Wuppertal, Germany

This abstract is available from: http://www.biomedcentral.com/I47I-22I0/7/SI/S9

(c) 2007 Lapp et al; licensee BioMed Central Ltd.

\section{Background}

BAY 58-2667 is a soluble guanylate cyclase (sGC) activator that acts independently of nitric oxide (NO) and haem. Data from preclinical studies show that BAY 582667 preferentially dilates diseased vessels, without the development of tolerance [1]. In healthy humans, this novel agent has a favourable safety profile and is well tolerated. We hypothesized that BAY 58-2667 would improve cardiopulmonary haemodynamics and be well tolerated in patients with acute decompensated heart failure (ADHF).

\section{Materials and methods}

This was a non-randomized, uncontrolled, unblinded, multicentre phase II study in patients with ADHF (pulmonary capillary wedge pressure $[\mathrm{PCWP}] \geq 18 \mathrm{mmHg}$ ). After initial dose-finding studies (part A) using 50, 100, 200 and $400 \mu \mathrm{g} / \mathrm{h}$, respectively, BAY 58-2667 was evaluated (part B) using a starting dose of $100 \mu \mathrm{g} / \mathrm{h}$, which could be titrated after $2 \mathrm{~h}, 4 \mathrm{~h}$ and $6 \mathrm{~h}$ to doses between $50 \mu \mathrm{g} / \mathrm{h}$ and $400 \mu \mathrm{g} / \mathrm{h}$, depending on the haemodynamic response. Haemodynamic parameters were measured by pulmonary artery catheter and impedance cardiography.
Patients were categorized as responders if their PCWP decreased by $\geq 4 \mathrm{mmHg}$ compared with baseline. Thirtythree patients were eligible for the safety evaluation and 30 for the haemodynamic evaluations (part B).

\section{Results}

Haemodynamic parameters at baseline were: PCWP, 25 $\mathrm{mmHg}$; right atrial pressure (RAP), $13 \mathrm{mmHg}$; mean pulmonary artery pressure (PAPmean), $36 \mathrm{mmHg}$; systolic blood pressure (SBP), $119 \mathrm{mmHg}$; systemic vascular resistance (SVR), $1581 \mathrm{dyn} \cdot \mathrm{s} \cdot \mathrm{cm}^{-5}$; heart rate (HR), 76.7 beats per minute (bpm); and cardiac index, $2.1 \mathrm{~L} / \mathrm{min} /$ $\mathrm{m} 2$. Final doses of BAY 58-2667 after $6 \mathrm{~h}$ of infusion were: $50 \mu \mathrm{g} / \mathrm{h}(\mathrm{n}=2) ; 200 \mu \mathrm{g} / \mathrm{h}(\mathrm{n}=12) ;$ and $400 \mu \mathrm{g} / \mathrm{h}(\mathrm{n}$ $=16$ ). Compared with baseline, a $6 \mathrm{~h}$ infusion of BAY 582667 reduced PCWP by $7.9 \mathrm{mmHg}$, RAP by $2.9 \mathrm{mmHg}$, PAPmean by $6.5 \mathrm{mmHg}$, SBP by $13.9 \mathrm{mmHg}$ and SVR by $597 \mathrm{dyn} \cdot \mathrm{s} \cdot \mathrm{cm}^{-5}$, while increasing $\mathrm{HR}$ by $4.4 \mathrm{bpm}$ and cardiac index by $0.82 \mathrm{~L} / \mathrm{min} / \mathrm{m}^{2}$. The responder rate was $53 \%$ after $2 \mathrm{~h}, 83 \%$ after $4 \mathrm{~h}$ and $90 \%$ after $6 \mathrm{~h}$. BAY 58-2667 was well tolerated. Of the 33 patients, six individuals reported 11 adverse events (AEs) of mild-to-moderate intensity and there was one serious AE. Three AEs were 
related to the study drug (hypotension and sickness) and eight were not. There was no evidence of tachyphylaxis.

\section{Conclusion}

These first clinical results with BAY 58-2667 in patients with ADHF demonstrate the potential of this new therapeutic principle. In patients with ADHF, continuous parenteral administration of BAY 58-2667 was well tolerated and induced potent arterial and venous vasodilation, which resulted in significant reductions in cardiac preand after-load and an increase in cardiac index. These data also suggest that a pool of oxidized or haem-free sGC is present in human ADHF; these forms are preferentially activated by BAY $58-2667$.

\section{References}

I. Stasch JP, Schmidt PM, Nedvetsky PI, Nedvetskaya TY, Kumar A, Meurer S, Deile M, Taye A, Knorr A, Lapp H, et al.: Targeting the heme-oxidized nitric oxide receptor for selective vasodilation of diseased blood vessels. J Clin Invest 2006, I I 6:2552-256 I.

Publish with Biomed Central and every scientist can read your work free of charge

"BioMed Central will be the most significant development for disseminating the results of biomedical research in our lifetime. " Sir Paul Nurse, Cancer Research UK

Your research papers will be:

- available free of charge to the entire biomedical community

- peer reviewed and published immediately upon acceptance

- cited in PubMed and archived on PubMed Central

- yours - you keep the copyright

Submit your manuscript here:

http://www.biomedcentral.com/info/publishing_adv.asp 